\title{
N. AKIYAMA, M.D.: THE RELATION OF THE CERUICAL SYMPATHETIC CHAIN TO THE AUDITORY ORGAN \\ First Report Clinical Observations
}

\section{頸部交感神經 と聴器との關係}

\section{第一篇 盬 床的觀 察}

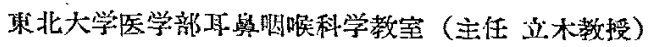 \\ 秋出登
}

1. 琵雷

自律神経系の研究は 18 世紀の初頭より行われ， 19 世紀の終りから20世紀の初わにかけて最高調以 達し，元の間 Langley により略体型方確立され， これが研究は增々精細となつて来ている。しかしな がら今後なお究明学要する問題は多く, 就中自律神 経と聴器の関俰に就いては未だ定説なく臆則の域を 脱しない、部分が少くない。

19 世紀末船量の原因として前庭器が注目せられ， Barany (1910)，Abels (1924) 等に上り原因が前 逞器の刺㦸による事が確認せられ，前庭器と自律神 経芰配下の諸䁍器との閏保が逐次明かとなり，前庭

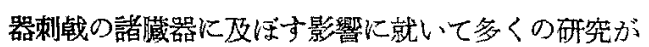
行われた。

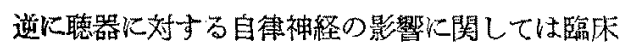
的には旧くより篗察されているに拘らず実験的研究 は割合に少い，䠋床的には Polizer (1908), Lermayez (1919), Kobrak (1922), Brunner (1925) $\mathrm{K}$ 上り記載され，Polizer (1908) は急激に垷最, 難 聴, 耳鳴，不快感支来大す疾患を Angioneurotische Akusticuslähmung として記載し, Lermoyez は内耳動脈の前庭及び期牛款枝の Angiospasmus により期聴，矓最定来たす症例を提示し，Kobrak (1922) は Angioneurotische Oktavkrise なる病 名を記載し，自律神経系の不安定の為に内耳儿充 血及び費血を生ずるのが原因であるとし，Waar (1923) は百倍の Ohrmikroskop を使用し自律神

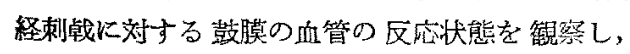

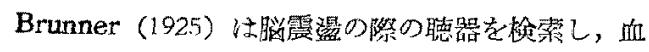
管の变化及び内外リンバ腔に渗透性出血を㒛め，自 $11-19$
律神経系の階碍による循環障碍を原因として举げ新 K Otitis interna vasomotorica なる名称を提唱 している. Partmann (1930) は Meniere 症候群 と Lermoyez 症续群と学剂比し，両掟候群之血 管神経と密接な関保があるとし，又栭部の手術後に

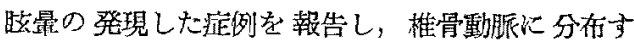
る交感神経線維が切断された為々解秎し，Teracol

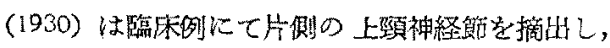

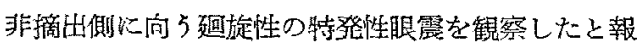
告している。

これらの諸家により論ぜられた疾病は所謂 $x=x$ ル氏病の概念上類似のもので自律神経系の失調が矤 病の主要なる原因の一つとして数点られて祘り，内

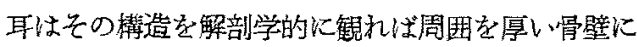
囲まれた狄小な器官で，大部分が比較的長い、経過を 取る終末動脈の内耳動䛲により血液を供給されてい る故以血管運動神経の些細な变調的神経刺战仁变古 られ大なる自覚的感筧を起し，頻へたる自律种経原 の变調は眲器以器質的变化を子起し得る事が容易心 推定し得られる。徉つて原因不明の矓最，難聴，耳

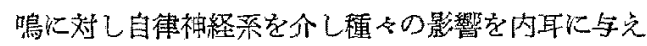

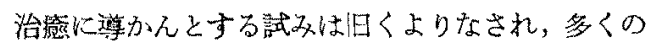

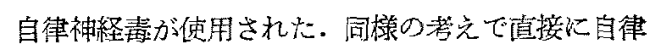
神経梁に外科的侵翼を加之迷路機能を正常に居さん として Ferri (1903) が䫫部交感神経の跓断を行つ たのを初めとし，Portmann Cantel 等により詿み られ，最近C沬 Passe (1948) により 星状神経節 の可除々第 2 第 3 胸神経節の節後線䧽の切渐が行方

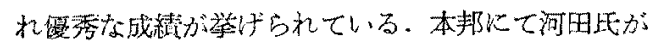
神経性難㯖の治療に上頸神経簛のラシウム照射を行 
つているのる同様の観点からと思われる。

私は立木教授の御指導の下に試獣として成熟家鬼 を使用し，聴器と最る関係が梁いと考它られている 项部交感神経の主要なる上栭神経矂を摘出し，交感 神経が如何なる影暚を聴器に与えているかを臨床的 並に病理組織学的に筧察した。

\section{2. 寅跲方法}

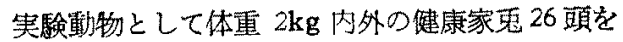
使用し，予め耳鏡検查及び前庭譏能検查を行つて正 常なることを確めた後俸験に供した。

上頸神経節の摘出は家象劣腹位に固定し四肢を緊 猼し支柱を以て雨側下顎骨を挾み頸部を伸展せし わ，皮膚の剃毛消毒の後に正中線にて舌骨の高さよ

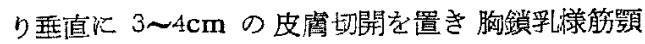

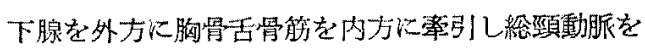
現し，更に総頸動脈の内外项動脈に分枝する部分を

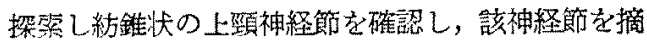
出し上万下方に向5神経線維を切断した。

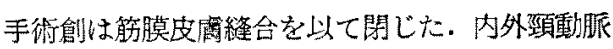
の分枝状態は㮔々の異型があり，各家鬼化てかなら ずしも一定していない。

埃查事項 全身所見，特発性眼稂，身体平衡障 碍, 異常頭位眼震, 廻転性後眼震, 温度性腿震, 各 璉耳石反射，音響性耳介反射に就いて検查した。迴 転性後腿震は家身を固定器に入水 15 秒 10 迴転の速

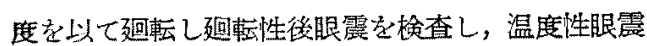
は全例火施行するを得なかつたが成㣱を一定ならし める為に $60 \mathrm{~cm}$ の高さに500cc を受容するイルり ガートルを置き期手をして家禹を腹位に固定せしめ $17^{\circ} 50 \mathrm{cc}$ の冷水各各片側耳に注入して眼震潜伏

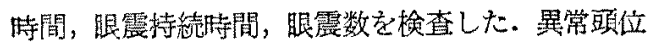
眼震は特発性眼震が認められなくなつた後に側位頭

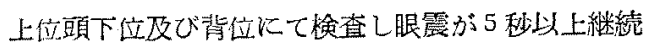
して脀められたものを記載した。

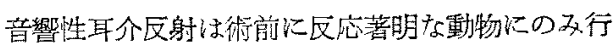
つた.

\section{3. 兴驗成耧}

各症例の臨床的所見は第1図，第2 图に坟示した が，廻転性後眼震倠温度性眼震值は代表的な症例に
就いてのみ第 3 図，第4 図に表示した。

实媛成綪图第 1 图)

\begin{tabular}{|c|c|c|c|c|c|c|c|c|c|c|c|c|c|c|}
\hline \multirow{2}{*}{\multicolumn{2}{|c|}{ 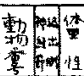 }} & \multicolumn{4}{|c|}{ 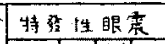 } & \multirow{3}{*}{ 潅 } & & \multirow{2}{*}{\multicolumn{4}{|c|}{ 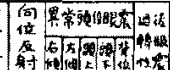 }} & \multicolumn{2}{|c|}{ 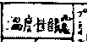 } \\
\hline & & 万舟 & $y_{4}$ & & & & & & & & & & & \\
\hline 6 & $65_{40}^{250}$ & & & & & & + & + & \pm+ & & $t$ & - & - & - \\
\hline 8 & $5{ }^{20} 8$ & 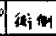 & $2^{\frac{1}{3}}$ & $6 \pi$ & $-k 4$ & $\rightarrow$ & + & + & + & & & - & - & +1 \\
\hline 11 & $t^{24}$ & 7 & 6 6 & & 小五 & $\rightarrow$ & $I$ & + & \pm & & & \pm & - & + \\
\hline 12 & $55^{210}$ & 街伴 & $4^{\circ}$ & $5 n$ & 水平 & $\rightarrow$ & \pm & \pm & + & & & - & it & $\pi$ \\
\hline 13 & $t^{2}$ & 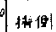 & $2 \%$ & $\mid \begin{array}{ll}39 \\
9 \rightarrow 4\end{array}$ & 29 & $\rightarrow$ & + & \pm & $+=$ & & I. & - & - & + \\
\hline 14 & $t 0^{21}$ & & & & & $\rightarrow$ & + & + & + & & 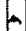 & - & - & + \\
\hline 15 & $\sqrt{2} 23$ & 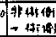 & 57 & \begin{tabular}{|l|}
$2 \pi$ \\
$5 \pi$ \\
\end{tabular} & $-k P$ & $\leftarrow$ & + & + & + & & & - & \pm & \pm \pm \\
\hline 17 & $6 \frac{26}{8}$ & 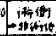 & $5^{5}$ & 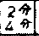 & * & 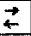 & \pm & + & ++ & & & - & & \\
\hline 18 & 5 & & & & & $\leftarrow$ & + & + & + & & & H & & $t$ \\
\hline 14 & 5.250 & Wate & $7^{7}$ & 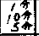 & *ki & 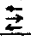 & + & + & + & & & \pm & & \\
\hline 20 & $\mid \frac{10}{213}$ & 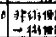 & 3 궁 & $\begin{array}{r}154 \\
34\end{array}$ & 1.4. & 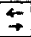 & + & + & +- & & 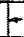 & + & - & - \\
\hline 21 & $160^{180}$ & 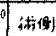 & $3^{3}$ & $\begin{array}{l}37 \\
20\end{array}$ & $2 k$ & $\rightarrow$ & + & + & + & & & - & & \\
\hline 23 & $t_{2}^{210}$ & 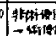 & 5 年 & \begin{tabular}{|l|}
87 \\
$25 *$ \\
\end{tabular} & *⿻ & $\rightleftarrows$ & + & \pm & + & & & - & \pm & \pm \\
\hline 24 & $f z z^{200}$ & & & & & $\leftarrow$ & + & \pm & +1 & & & \pm & & \\
\hline$x$ & $\sqrt{t}$ & 同维住 & $\exists \pi$ & $2^{n}$ & 太辇 & 4 & + & + & + & & & - & $\pi$ & - \\
\hline 26 & $\pi \sqrt{\frac{x}{8}}$ & 排的保 & $3^{\text {* }}$ & $20^{4}$ & 水平 & $\rightarrow$ & + & \pm & + & & & $t$ & + & - \\
\hline 27 & $17 \frac{200}{20}$ & & & & & $\leftarrow$ & + & + & + & & & $t$ & - & - \\
\hline 28 & $3 \pm 129$ & (n) & $10^{4}$ & 2 19 & 水平 & $\Xi$ & + & \pm & + & $1-1$ & & + & & \\
\hline 39 & 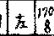 & 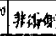 & $46^{\circ}$ & & 水平 & - & + & + & \pm & & & H & & \\
\hline 40 & $0\left|\frac{1}{2}\right| 190$ & 做儌 & $3^{n}$ & 201 & & + & + & + & +1 & $\leftrightarrow$ & & + & & \\
\hline
\end{tabular}

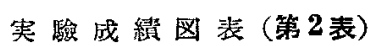

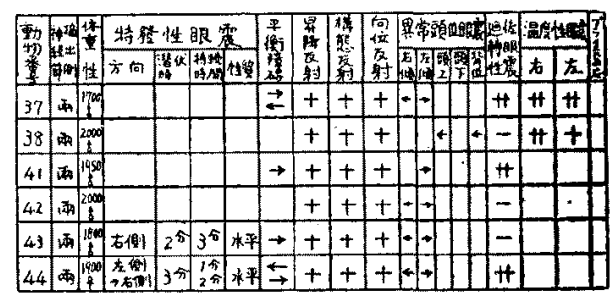

詰 1. 特発性眼震及び異常頭位眼霞の↔の।

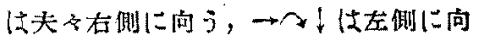
う水平型，超旋型，垂淔型の眼震を示 す。

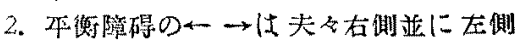
に向方蒜す。

3. 諸耳石反射の十H士一仕正常, 克進, 稚々減退，減退老示す。

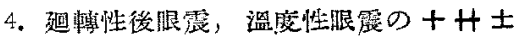
一正正常，充進，稍々減退，減退灻示す。

\section{4.小括}

A) 全身所㫕

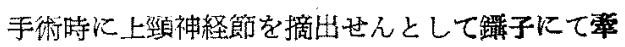

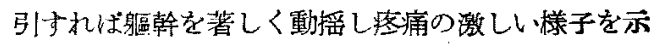
$11-20$ 
実 驗 成 綪图裴（第3 圈）

\begin{tabular}{|c|c|c|c|c|c|c|c|c|c|c|c|c|}
\hline \multirow{3}{*}{ 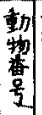 } & \multirow{3}{*}{ 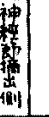 } & & \multicolumn{4}{|c|}{ 造精性淩眼震 } & \multicolumn{6}{|c|}{ 温度性眼震 } \\
\hline & & & \multicolumn{2}{|c|}{ 右，迥轒 } & \multicolumn{2}{|c|}{ 左建䡚 } & \multicolumn{3}{|c|}{ 右 倒 } & \multicolumn{3}{|c|}{ 左 側 } \\
\hline & & & 样 & 㩆 & 静 & 妵 & 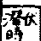 & & 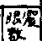 & $\sqrt{6}+\infty$ & 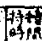 & 5 \\
\hline \multirow{5}{*}{6} & & 和㬂 & $12^{\prime \prime}$ & 12 & $12^{\circ}$ & 12 & $20^{\circ}$ & 28 & 41 & $18^{\circ}$ & $39^{\circ}$ & 46 \\
\hline & & 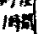 & $10^{\prime \prime}$ & 7 & $7^{\circ}$ & 7 & $26^{*}$ & $20^{\circ}$ & 24 & 26 & 29 & 38 \\
\hline & d & 解 & $13^{n}$ & 7 & $7^{\circ}$ & 7 & & & & & & \\
\hline & & 18ni & $13^{\prime \prime}$ & 11 & 7 & 6 & $21^{*}$ & $34^{\prime \prime}$ & 24 & $20^{\prime \prime}$ & $29^{\prime \prime}$ & 36 \\
\hline & & 4 & $13^{\circ}$ & 12 & $7:$ & 6 & $20^{\circ}$ & 26 & 29 & $18^{\circ}$ & $3 i$ & 50 \\
\hline & & 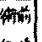 & $8=$ & 19 & $8^{\prime \prime}$ & 19 & $\eta^{\mu}$ & $41^{\circ}$ & 58 & $7^{\circ}$ & 48 & 60 \\
\hline \multirow{2}{*}{8} & t & & $9^{\circ}$ & 17 & $8:$ & 20 & & & & & & \\
\hline & 01 & & $: 9^{\circ}$ & 17 & $6^{\circ}$ & 12 & $15^{4}$ & $25^{\prime \prime}$ & 18 & $115^{\prime \prime}$ & 37 & 53 \\
\hline & & 4 & $11^{4}$ & 20 & 8 & 13 & $20^{\circ}$ & $30^{\circ}$ & 15 & 10 & 44 & 56 \\
\hline \multirow{5}{*}{15} & & 林为 & $9^{4}$ & 17 & $8^{4}$ & 17 & $7^{*}$ & & & $7^{\circ}$ & 1 io & 120 \\
\hline & & th & $7^{*}$ & 11 & $6^{4}$ & 12 & 9 & & 91 & 9 & 15 & 113 \\
\hline & 左 & यAn & $8^{\prime \prime}$ & 11 & $7^{\circ}$ & 12 & & & & & & \\
\hline & & & $7^{*}$ & 13 & $9 *$ & 16 & & & & & & \\
\hline & & int & $8^{\prime}$ & 14 & 9" & 15 & $10^{*}$ & $45^{\circ}$ & 771 & $10^{\circ}$ & 47 & 87 \\
\hline
\end{tabular}

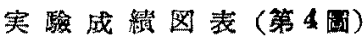

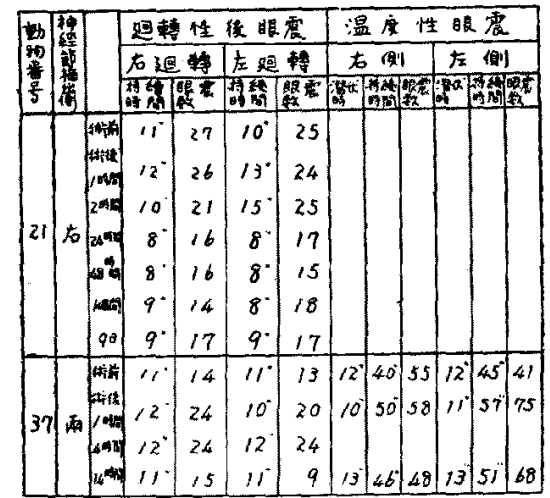

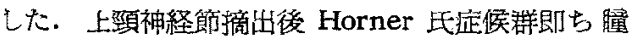

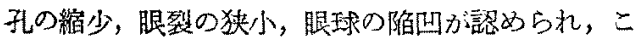
れらの症状は比整的長く継綕して親察出来たが次第 に不明瞭となつた。矢の仙術側の耳介，眼铪，眼結 膜に充血が生じ，特に耳介の充血は更に著明であつ

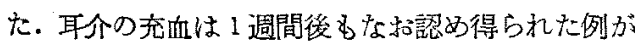

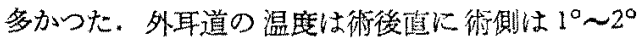
或はそれ以上に上年し，非手術側は㱠ど变化がなか つた。術側の外耳道は発赤し，鼓膜は鼓荧周边部血 管の充血が認められた例があり，鼻空は術側の粘膜 の発赤及び水样性鼻汼の分泌過多が認められた。術
後家象は運動不活発となり食兹が減退したが次第に

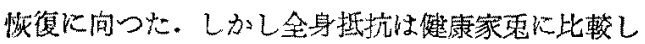
減退している如くで象娩绝上なんらの前駆症状なし に死亡した例が多がた。

B) 前庭器所㫕

1) 特発性腿震, 頭震更び平衡障碍

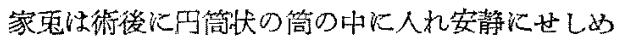
ると 20 例中 15 例江数分の潜伏期孝置き緩急成分の 明かな排幅の大なる水平性の特発性眼霹が認るら

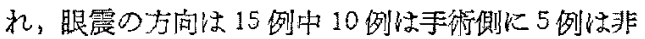

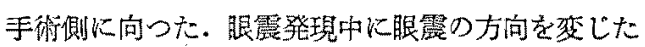
例当少くなく2例は最初に術側の力向に発現してい

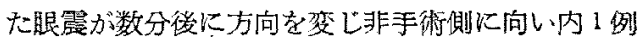
は車び方向变変じ術側に向つた。3例恃最到に非手 術側の方向に発現した眼震が中途にて方向を变し術 側に向つた。它の他眼震が一旦消失し一它時間を置 き反復出現した例も翟められた。眼震持続時間は短 か心例ては1分以内長い例で佉20 分閏に及九だ。

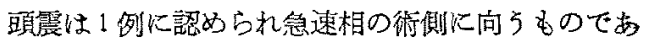
つた。平衡障碍は多くは特登性腿震の発現前に認め

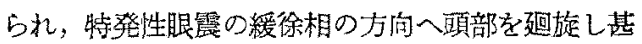
しき場合性頭部の傾斜分加り下影索前肢に附着させ

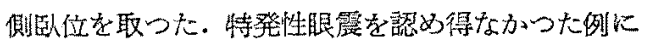
ても特発性眼震の発現例之同じく手術側或は非手衡 側入頍部を迴旋し平衡障碍が認められた。特登性眼 震の力向を变ずる際は眼震緩徐相の力向入迴旋して

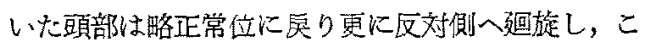
れにともない特登性眼祳は一眭認められなくなり， 後に再び以前之方向の基る特発性眼震が発現した。 特発性腿震の数は著明に発现しな例にては1秒に 回の割合で出つたが多くは 5 秒に 1 回以下の割合て 西つた。雨側上頸神経節摘出例は6 例中に2 例の特

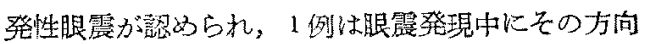
变变じた。

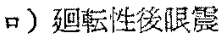

眼震の数及び持続時閒は術後に衡側延転, 非術側

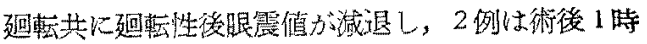
間ないし3時間にて迴䞑性後眼震值が九谁し4例は 手術直後に不昰な成䅡を示したが24 時間後にはい

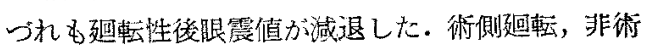
例廹転を比䔩すると特に非術側廷転にて迴転性後眼 
震值の诚退が堵明であつたのが 3 例あり，日㭙の経

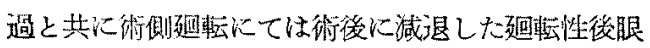
誫值が恢樭の傾向を示した4例があり，2例は1週 間から10日で術前值迄掋復した。術側迴転, 非術

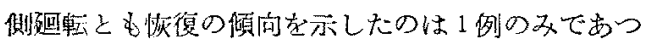
た。両側上项神経邻摘出の6 例炒側上项神経節摘 出例と同じく街後论迎刦性後眼震值は減退したが手 術直後化一眭的汇迴転性後眼震值の元准した 3 例が あった.

\section{八）温度性眼震}

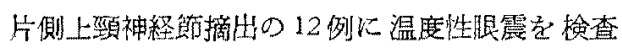
L，6列は両側の温度性眼震值が減退し，5例は術 側の温度性眼震值のみ減退し非術側の变化は明かで なく，1例は政側ともに变化が明かでなかった。術

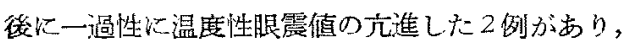

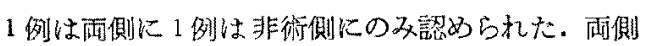
の温度性眼震檤の減退した6 例の内 2 例は特儿術側 の温度性腿震值の減退が顕著であつた。雨側上栭神

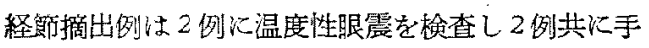
術直後に一過性の温度性眼震值の元進が雨側に見ら れたがその後の検查にて減退の傾向を示した。

\section{）異常頭位眼震}

片側上莖神経節の摘出例 20 例中 17 例飞側位にて

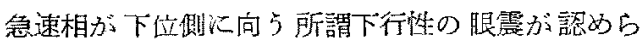
れ，左右网側位にて認められたのは12例，左側位 或は右側位のみ汇馀められたのは5列であり，3例 は術側索上側位にした際に2 例は術側を下位側にし

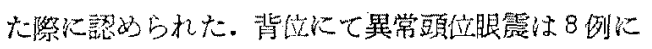

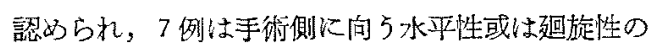

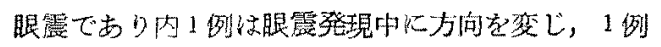
は垂直性の眼震であつた。頭上位にては5例記認め

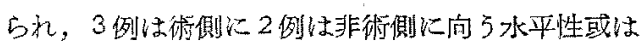
名旋性の眼震であり，頭下㕸にて眼霞の認められた 例はなかつた。異常頭位眼震は側位にて最も多く証 められ，背位がこれに㳄ぎ，頭上位にて㒛められた 例は少く且つ腿震が艮続して認められなかつた。側 位にて異常頭位眼震の認められる期間は長く数週間 後にもなを認められた例があつたが背位は比較的短 訝間に認められなくなつた。両側上頚神経節の摘出 例は6例印 5 例に左右両側位にて異常頭位眼震が認 ぬられ，背位にては 1 例に，頭上位儿ては2例異
常頭位眼震が認められた。

亦)耹石反射

傋態反射，向位反射，身降反射の淢退を認めた例 があつたがいずれも俥度のもので日時の経過と共に 恢復した。

へ）音響性耳介反射

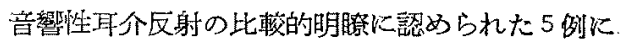
就いて検查し，4例は区射が減退し1例は变化が明 かでなからた。

\section{5. 考按}

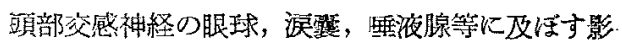
響に就いては以前より多くの研究があり，その概要 は成㫪に記載されている所であるが旧くより血管運

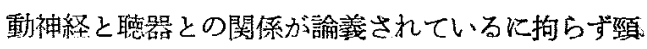
部交感神䅅々恥器との閣係を考究した䒠䮖は少く且 つ研究者により結論が異り未だ明確な見解が得られ， ていない. 本奏験々頸部交感神経の主要な神経節の 一つである上頸神経節を手術的济出し臨床的所見。 そ日時の経過と共に観察したのである。

術後に Horner 氏の症候群はいずれの家鬼にる 術側に発現し，その他に術側の耳介の発赤術側の外 耳道温度の上开が篗察され，これらの諸拝状は日時 の経過と共に不明膫となつて来るが耳介の発赤は肉 眼にて術後 1 週間迄锶察し得られ Horner 氏の症: 候群は 3 週間を経渦しても認め得られる例が多い。

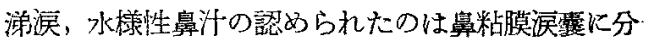

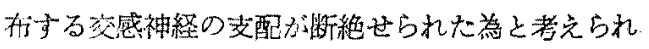
古.

上頸神経節の摘出後の特発性眼震の発現に就いて は僅に Partmann (1928) がこれに言及し Terracal. (1930) が臨床例にて非手術側に向 5 特登性眼震を 観察したと記載している以外交苚に記載なく注目す べき事項である.眼震の万向は10 例は非術側化5 例は術測飞向つて発見し中途にて眼震の方向を変じ た例或は一眭腿震が中絶し再び眼震の発現した例が認められた。眼震は高崎 (1926) のピロカルピンを 外耳道に注入した实験, 内藤 (1950) のピロカルビ ンを内耳”動脈に注入した実験, 河本 (1954) のピロ カルビンを鼓室に注人した实験と眼震の発現の機序 が類似した点があると考方られるが眼震の力向は本 
実験では術側に向つた例が多く高崎河本の笑験の絬 果とは相違し内藤の実験の結果に一致した。

異常頭位眼祳は長谷川 (1943) が滛部交感神経節 摘出後に側位にて眼震の下位側に向 5 下向性の異常 頭位眼震を認め，又頭下位にてす異常㽬位眼震が非 手術側に向つて発現するのて認めて居り，笑験動物 の異常頭位の斎たらす物理的状沿の変化就印血液の 变化に対処する譑節作用が頸部紊感神経節の摘出に よって発現しないためと解稂している。本银験では 片側上頸神経饰摘出例，両側上頸神経節摘出例之も 側位にて大多数に異常頭位眼震が認如られ下向性の 眼震であつた。背位にては片㑡上栭神経節摘出例に 多く認的的眼震の性質は水平性，迴旋性，琶直性 を示し一定せず，眼震の方向は水平性及び迴旋性眼 震では手術側へ向つた，頭上位にては片側上頸神経 節摘出例の 4 例再側上頙神経節摘出例の1 例に異常 頭位眼震を認めたが眼震の方向は一定して居らず総 ベて一過性化て眼震の継続した例はなかつた。

迴転性後眼震は Demetriades (1925)は片側の 上頸神経節を摘出した家鬼で数ケ月後に両側の迴 転以て超転性後眼祳值の減退があつたと記載し，

Cantel u Grahe (1931) 性同じく片側の上頸神経 節を摘出した家鬼で10日後に両儧の而転にて迎転 性後眼震值の減退があつたと記載している.本実歌 では片側の上顼神経節の摘出にて術啳に变化は耐側

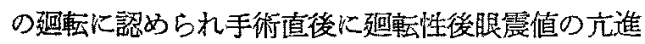
を示した例す少数あつたが日時の経過と共に減退し た.又術後に迴転性後眼震值の淢退を示し, 并の後の 検查で改復の傾向を示した例があつたのは手術によ り薏起せられた内耳の自律神経系の失赥が日時の経 過と共に或る程度調節せられた為と考完られる。

頸部交感神経の 町断後の 温度性腿震は Murphy (1933)によれば術側及び非術側にて術前に比較し 有意の差を認嫫倠かつたとし，吉武（1933）も同榜 の結論に達している.これ汇反し Gillard u Lannois（1925）は術側の温度性眼祳值の娍退安認め，

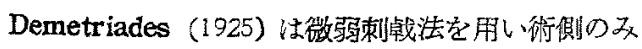
ならず非彷側にも剌战閶の低下を誌め, Cantele u. Grahe (1932) は冷刺㦸により術側の眼震数の減少 があり両側见潜伏期の延長があうたとしている。本 实験では片側の上頸神経節摘出例の大多数に術測の

$$
11-23
$$

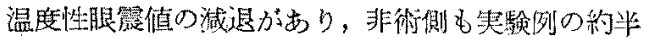
数に游退が認められ，迴軽性後腿震と同じく日侍の 経過々共洃復の傾向を示した例もあった。

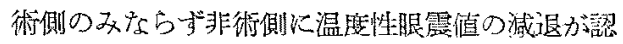
められたのは片側の頸部交感神経の影響が両側迷路 に文占事を示している。

耳石反射は竹中（1934）は钼部交感神経の片側或 は耐側の四断後に著明な变化がなかつたとし 本契 駼にては軽度の隇退を認めた例は专つたが短時日の 内恢復した。

音響性耳介反射は Demetriades (1925) はモル モットKて上頸神経節の摘出後 24 時間て㳦退の前 北を示し術後 2 週間で娍退しその後恢復の傾向を譛 めた例があつたとし小沢 (1936) は同じく術後の閑 退老認め，柳原（1936）はモルモットの音響性耳介 反射をミオグラフイオン上の煤型紙に描写し術後 5 時間迄観察し反射は元進したと記載している。

既に迷路に対する各種の自得神経毒の作用に就い ては以前より幾多の実験があり，その繥果は略明ら かとなつているが之等の央験は萖物自体の坦性を除 去することが出来ず交感神経到交感神経の刺战或は

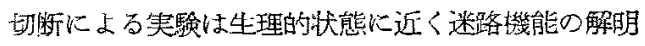
に重要である。解剖学的に顽動脈警には交感神経系 と考完られる神経節細胞が存在し動脈壁中を末梢迄

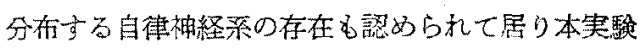
の如く阘側の上頸神経節の摘出を行つても聴器に分 布する交感神経を完全に除去したとは考方られず，

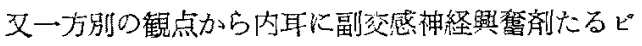
ロカルビンを作用させた実唤とも一部の共通点はあ るが同一視することは出来ない.片側の頸部交感神 経が雨側の内耳関聯性を有することは諸家の行つ た笑娩の共通の結前であり本笑験にても同梯で内耳 動脈は一本の脳应動脈より分枝している故にこの結 铪は当然であると思拝せられる。

\section{6. 結 論}

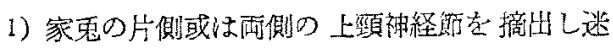

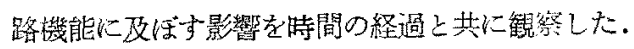

2）特発性服震は手術直後に片側の上频神経節摘 出例の三分の二汇認められ，眠震の力向江術側飞向 万例が多かつた。両側の上頸神経節摘出例は6 例中 
2 例に特発性眼震が馀められた。

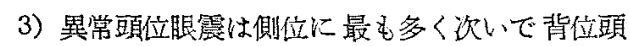
上位に琵められ，頭上位にて認められた例は少く且 つ一過性であつた，珙常頭位眼震の消失の順位は頍 上位背位側位の服であつた。

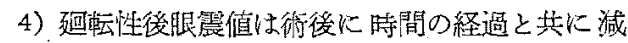
退したが手術直㣪に一時古進した例或心衡後に一旦

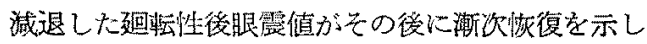
た列がすつた。

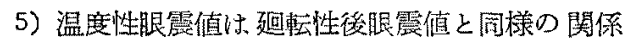

が認められ片側の上頸神経節摘出倐にてる衡側のみ ならず非手術側も減退を示し，術側の減退方非術囎 に比輘し強かつた。

6) 耳石反射忹術後に構熊反射向位反射昇降反射 の減退を認めた例が少数あつたが軽度であり短時日 のららに咴復した。

7) 音響性耳介反射は衡後に減退し，その後の烚 查にて恢復を示した例はなからた。

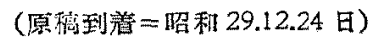

\section{N. AKIYAMA, M.D.: THE RELATION OF THE CERUICAL SYMPATHETIC CHAIN TO THE EAR-LABYRINTH}

Second Report Patho-Histrogical Observations

\section{頸 部 交感神 經と聴器との關 係 第二篇 病理組織學的觀察

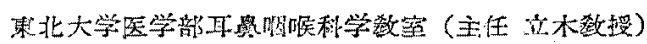

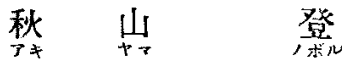

1. 緒言

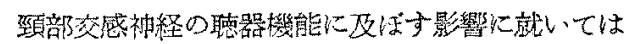

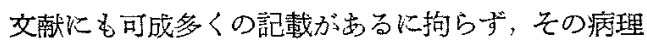
組織学的立場からの开究生滛に少く支献を选消する K Torrini (1913), 松㛊 (1919), Demetriades (1929)，小沢 (1934)，Rambo (1953) 算数氏を数

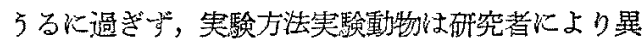
り，その蒰告も病変を示した部位が区るであり或は 病变を認めなからた等各ら異つた結論に到㹂してい b.

私は先きに片側又は両侧の上頸神経節摘出を試子

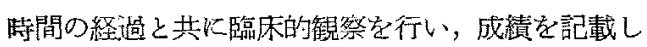

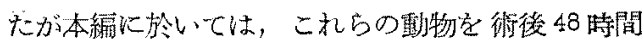
以内, 48 時閒以後 1 週間以内, 1 週問以後 3 週間以 内の3群に分与生体固定を行い，聴器を满理組織学 的に検索した結果に就いて記載する。

\section{2. 筫䴋方法}

奏験材料は第一編に記載した家鬼である。 上頸神経節摘出後に第1 群(48時閒以内に生体
固定)，第2 群（48時間以後 1 週間以内に生体固 定），第 3 群（1週間以後 3 週間以内に生体固定）に 分ち筧察したが実験の中途にて死亡した例或は生体 固定の不十分な例を除外した為炕第 1 群 8 頭，第 2 群 4 頭，第 3 群 6 頭，計 18 頭に就いて病理組織学 的所見を証載した。

生体固定は型の如く家鬼の体温に近く加温した生 理的食塩水を以て血管洗洛後，山川氏固定液を以て

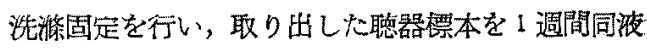
にて後固定を施し，脱死その他の珯操作を経てッニ ロイジンに包埋し $2 \% ， 4 \% ， 8 \% ， 10 \%$ とッニー1 ジンの濃裹を高めて行き，㘣つた標本を $15 \mu \sim 18 \mu$ の厚さの連続切片となし検鏡した：ツェロイシン硬 化不十分の標本では低澧度アルコール溶液に浸漬し 硬化を促准せしめた。染色はへマトキシリン，ェォ ジンの重染色を行つた。

\section{3. 宽路成䋖}

症例は生体固它法に成功し，その後の標本作成の 過程に於いて人工兴化を最小限に止めたと思われる 